\title{
EXPERIMENTAL STUDIES ON ACUTE AND SUBCHRONIC TOXICITY OF A NEW HERBICIDE, "PHENOTHIOL"
}

\author{
Mitsuru SHIRAKAWA*, Tadatoshi YAMAGUCHI*, \\ Seijiro FUKAMACHI* and Setsuro SUGATA*
}

\section{I . Introduction}

The production and use of herbicides increased dramatically during the last decade. Among a large number of the herbicides, chlorophenoxy compounds are probably the most extensively used chemicals for

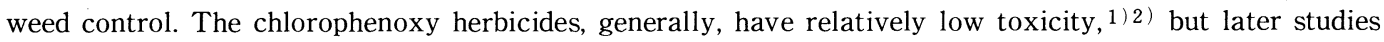
indicated that there were some toxicities following administration of large doses. ${ }^{3}$ )-7) "Phenothiol" is a new phenoxy herbicide, which has been studied and developed by Hokko-kagaku Industry Co. Ltd. It is important to investigate whether the herbicide presents little toxicity to man and animal when the new compound is available. At the present study, acute and subchronic toxicity of this compound was examined with mice and rats. Part of the study was reported previously. ${ }^{8)}$

\section{Materials and Methods}

(1) Material

The test compound used in this study was "Phenothiol", S-ethyl(4-chloro-2-methyl) phenoxy thioacetate and has a following structure:
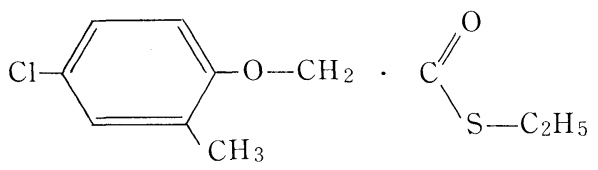

The compound is a white needle-like crystalline material and melts at $41-42^{\circ} \mathrm{C}$. The boiling point is $140-141^{\circ} \mathrm{C}$ at a reduced pressure of $0.95 \mathrm{mmHg}$. It is readily soluble in organic solvents (except in petroleum solvents) and sparingly soluble in water $\left(23 \mathrm{ppm}\right.$ at $\left.25.5^{\circ} \mathrm{C}\right)$. The test material used was Lot No.7 and $98.7 \%$ pure.

(2) Experimental animal

Experimental animals (5 weeks old ddy mice and Wistar rats) were purchased from Experimental Animal and Agricultural Coop. in Shizuoka and before use kept for 2 weeks in an air-conditioned animal quarter at temperature of $23 \pm 1^{\circ} \mathrm{C}$ and humidity of $65 \pm 5 \%$. Only healthy animals which were 7 weeks old were selected for the toxicological studies. At the time of start of the experiments mice weighed on the average around $31.1 \mathrm{~g}$ for male and $24.2 \mathrm{~g}$ for female. Rats weighed about $195.8 \mathrm{~g}$ and $138.5 \mathrm{~g}$ for male and female, respectively.

Animal foods were obtained from Nihon Clea Co. Ltd.

(3) Acute toxicity test

"Phenothiol" is insoluble in water and it therefore was added in $1 \%$ gelatin to make a final concentration of $6 \%$. The emulsion was administered once into the stomach with a specially-designed laboratory 
syringe. The number of death was counted 7 to 10 days after the oral administration. There were 10 animals for each group. $\mathrm{LD}_{50}$ was calculated by the method of Litchfield and Wilcoxon. ${ }^{9)}$

(4) Subchronic toxicity test

Subchronic toxicity test was carried out for 13 weeks. Foods which contained "Phenothiol" at various concentrations of $30,100,300$ and 1,000 ppm were prepared by mixing the test material with animal foods. The control group was given foods which contained no "Phenothiol". Groups, I, II, III and IV were fed diets which contained "Phenothiol" at 30,100, 300 and 1,000 ppm, respectively. For each group, 10 animals were housed in one cage. All animals were fed foods and water ad libitum. Daily intake of foods and water were recorded. Body weight of animals was measured once a fixed day of the week. Behavior besides growth of animals was also examined.

Feeding foods was terminated 13 weeks after start of the experiments. Animals were anesthetized with ether and cut open in the belly. Blood was collected with a syringe through the heart and immediately, erythrocytes, leukocytes, hemoglobin and hematocrit were checked. Glutamate-oxaloacetate transaminase (GOT) and glutamate-pyruvate transaminase(GPT) in the serum were also tested. Lung, heart, kidney, adrenal gland, testis or ovary, spleen, liver, stomach and brain were removed and weighed. Relative weight of each organ to body weight was calculated.

Pathological studies were carried out with those organs, intestine, cerebrum and cerebellum. Organs except brains and nerves were fixed in $10 \%$ formalin, embedded in paraffin and stained with hematoxylineosin. Brains and nerves were fixed in $80 \%$ alcohol, embedded in celloidin and stained with thionine.

\section{Results}

Acute toxicity test

Peroral $\mathrm{LD}_{50}$ of mice was 1,670 and $1,610 \mathrm{mg} / \mathrm{kg}$ for male and female, respectively (Table 1 ). That of rats was 960 and $930 \mathrm{mg} / \mathrm{kg}$, respectively, for male and female (Table 1).

Table 1. Peroral LD 50 of "Phenothiol" for Mice and Rats

\begin{tabular}{c|c|c|c}
\hline \multicolumn{2}{c}{ Mouse } & \multicolumn{2}{c}{ Rat } \\
\hline Male & Female & Male & Female \\
\hline 1,670 & 1,610 & 960 & 930 \\
\hline
\end{tabular}

Subchronic toxicity test

(1) General observations

All animals in each group were normal for 13 weeks throughout the experiments. There was no death.

(2) Intake of foods and water

Intake of foods by mice was variable ranging from 3.2 to $5.5 \mathrm{~g} /$ day $/$ head (Fig. 1). There is no significant difference between the control and the herbicide-fed groups. Intake of foods by rats in all groups somewhat declined with time (Fig. 2), but difference between the control and experimental groups is not significant. On the average throughout the experiments, intake of foods is $4.4,4.0,14.3$ and $10.5 \mathrm{~g} / \mathrm{day} / \mathrm{head}$ for male and female of mice and male and female of rats, respectively.

Intake of water is shown in Fig. 3 and 4 . There is no difference between the control and experimental groups. Average intake of water is $6.4,5.2,22.5$ and $18.1 \mathrm{ml} / \mathrm{day} /$ head, respectively, for male and female of mice and rats. 
$662(12)$
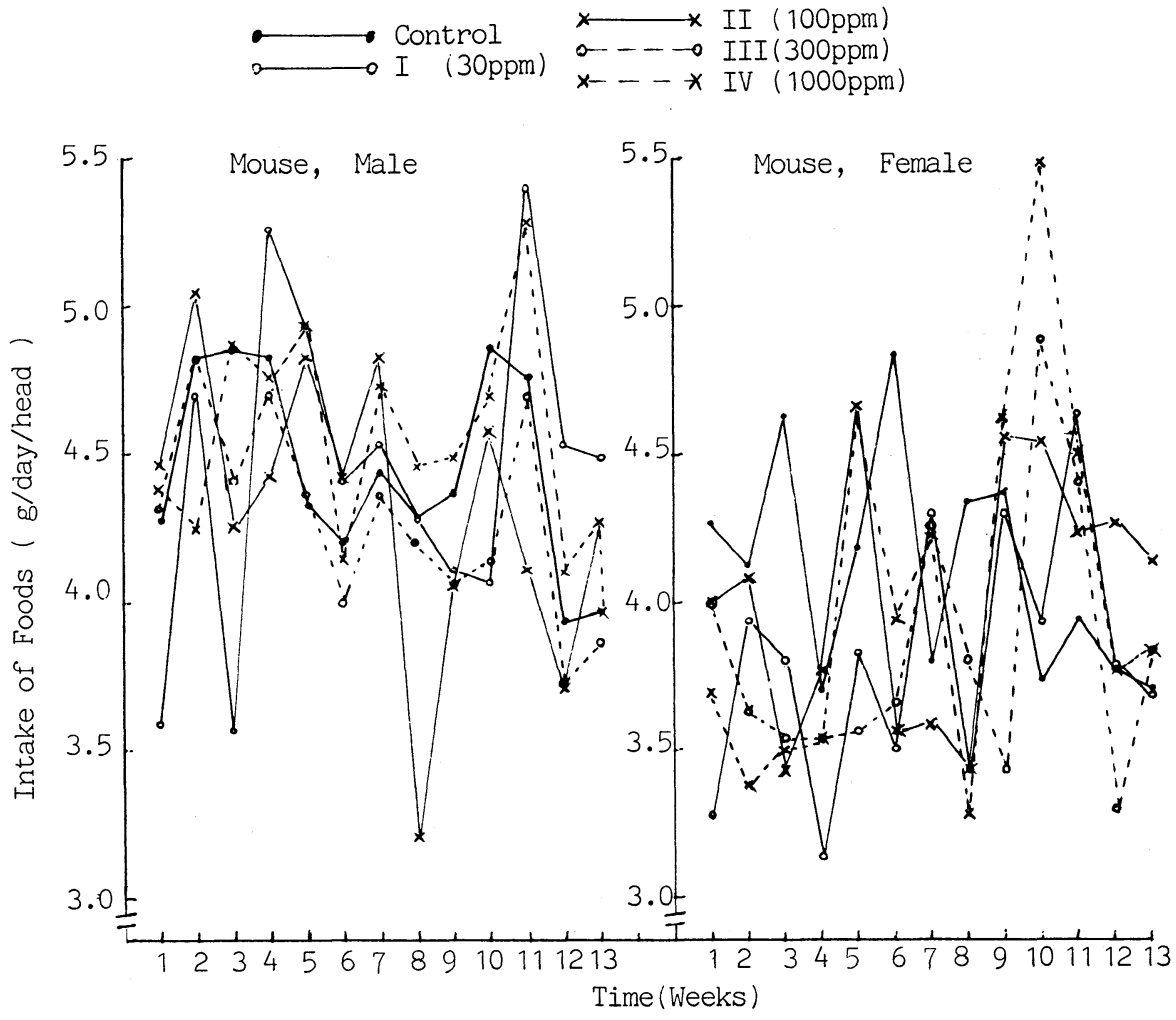

Fig. 1. Intake of Foods by Mice

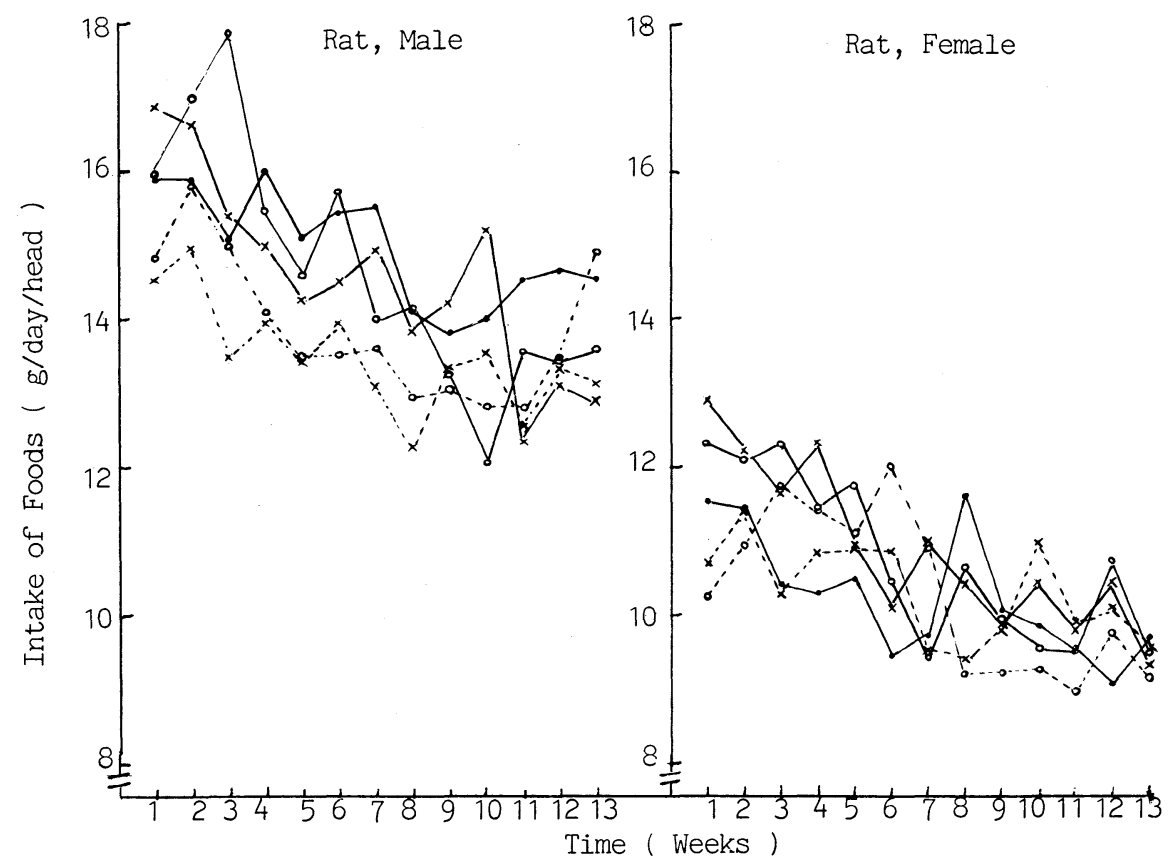

Fig. 2. Intake of Foods by Rats 


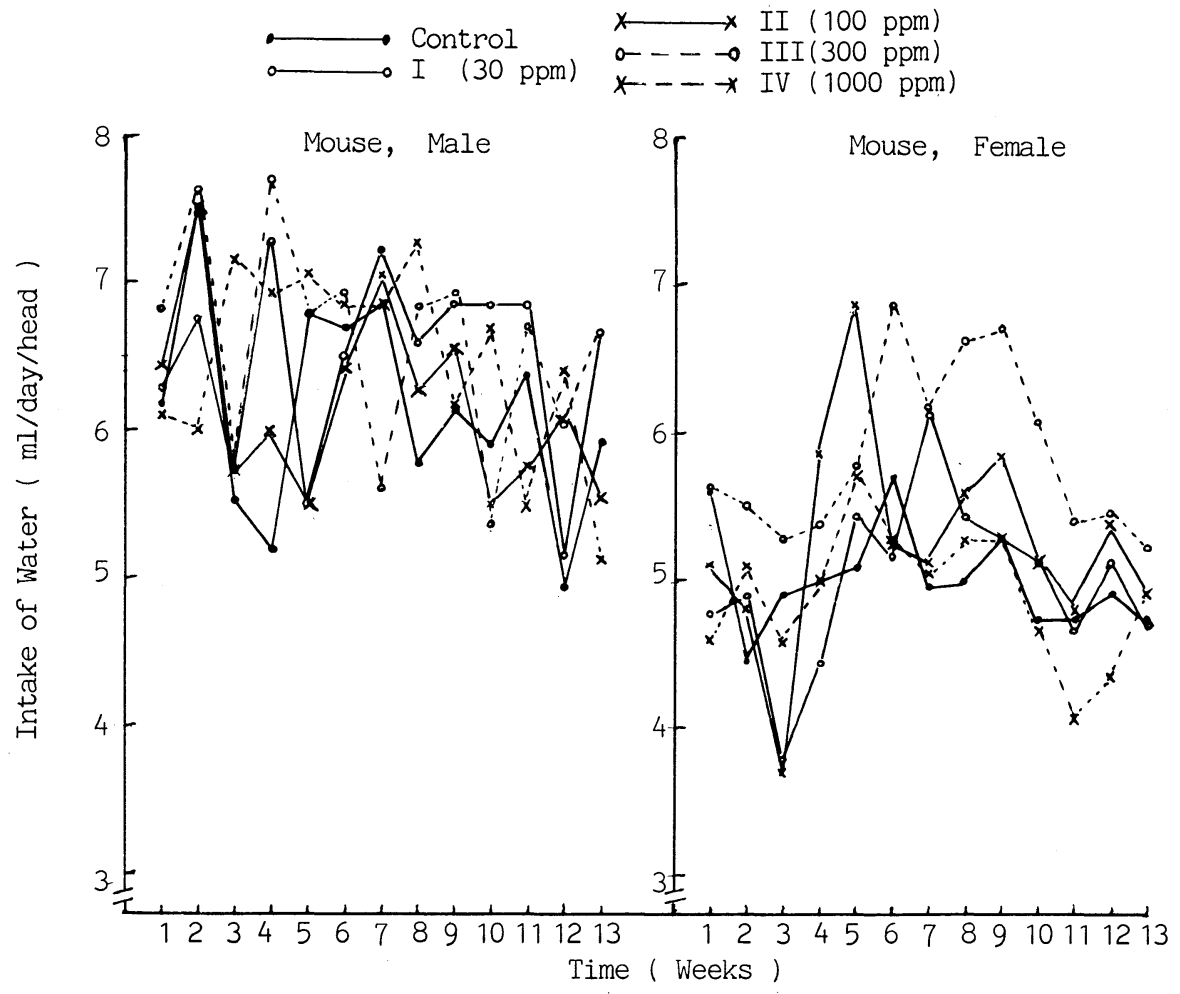

Fig. 3 Intake of Water by Mice

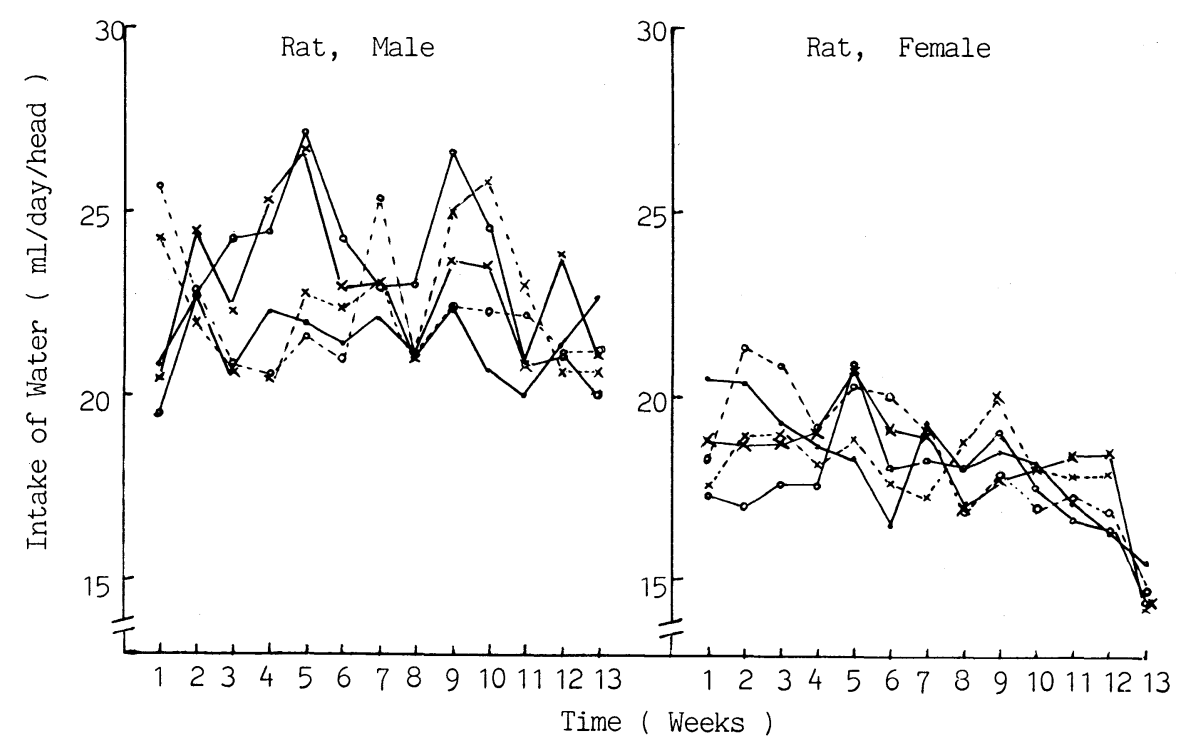

Fig. 4. Intake of Water by Rats

(3) Growth rate

Mice, both male and female, grew normally throughout the experiments (Fig.5). Rats also grew well with linear weight gain for male and gradual weight gain for female (Fig. 6). There is no significant difference in growth rate between the control and "Phenothiol" groups. 
664(14)

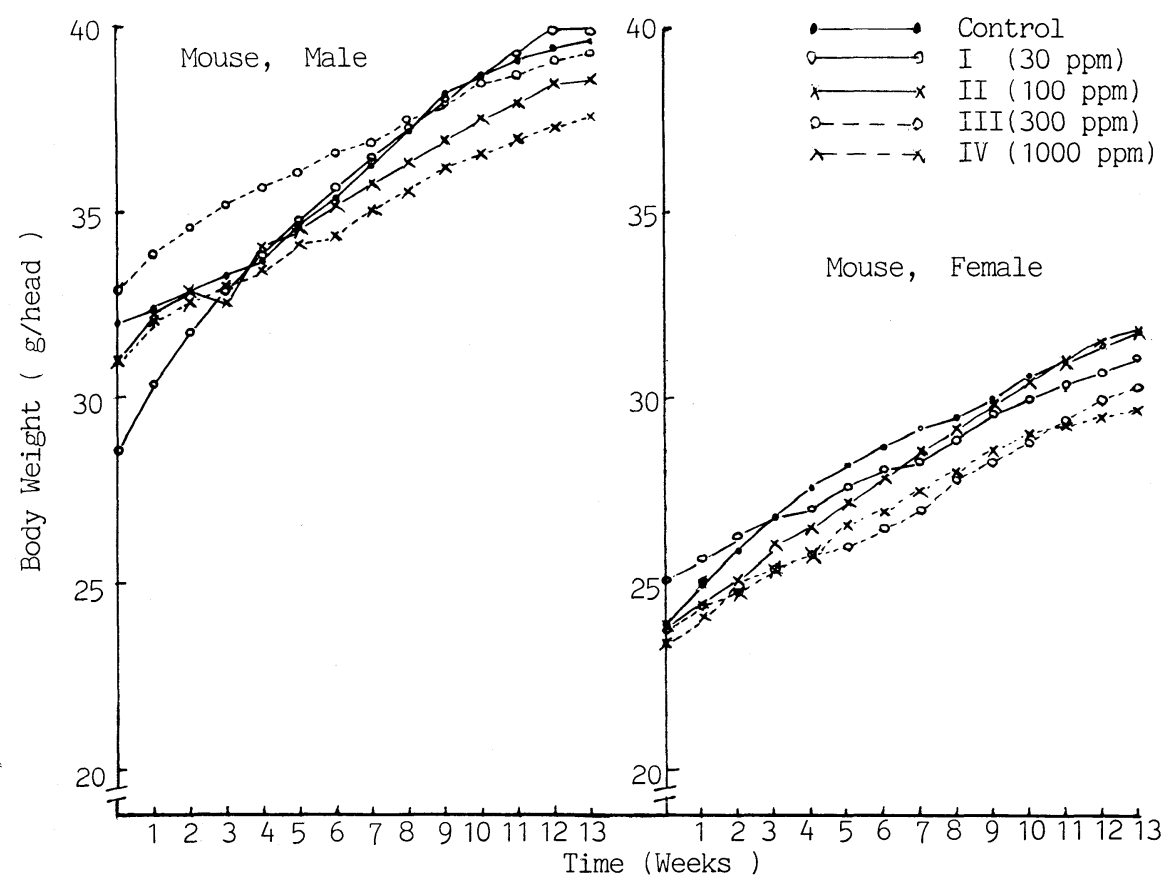

Fig. 5. Growth Rate of Mice

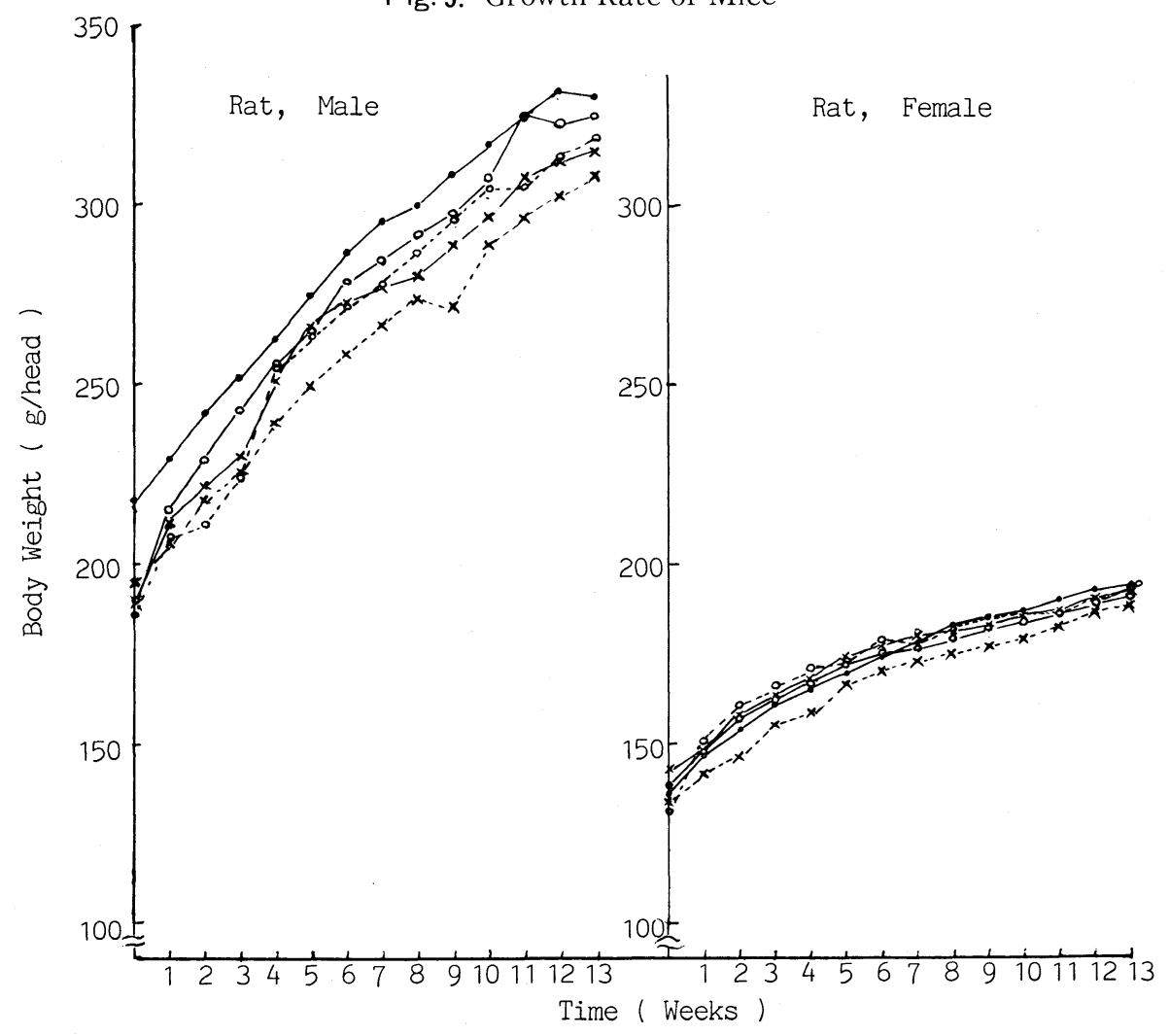

Fig. 6. Growth Rate of Rats 
(4) Intake of "Phenothiol"

"Phenothiol" added to foods was checked for its stability in diets 7 and 13 weeks after the preparation. Degradation or change in "Phenothiol" content was not detected even in 13 weeks old samples. Intake of the herbicide is plotted on the basis of intake of foods, content of the herbicide and body weight (Fig. 7 and 8 ). Average intake of the herbicide over a period of 13 weeks is shown in Table 2. Intake of "Phenothiol" was parallel to the increasing amounts of the herbicide added to foods.

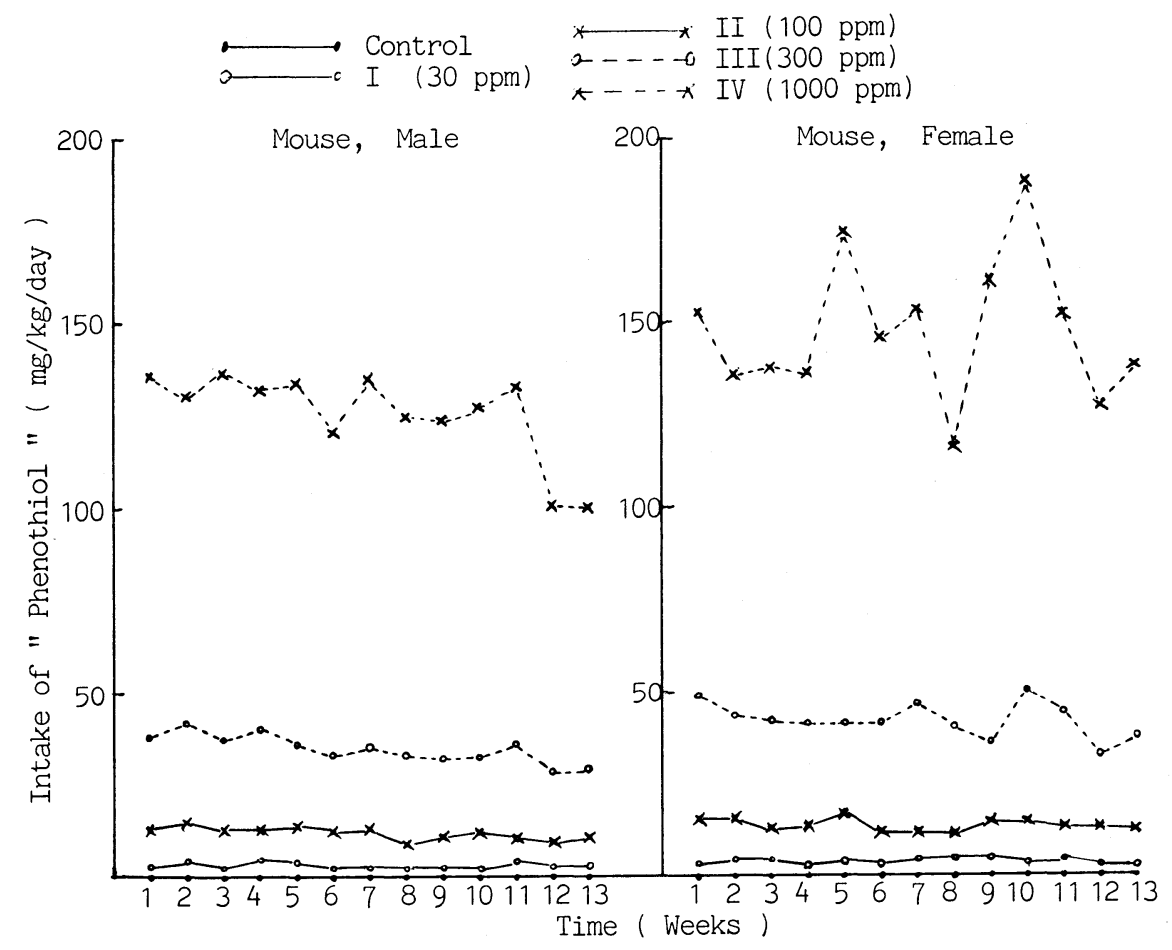

Fig. 7. Intake of "Phenothiol" by Mice

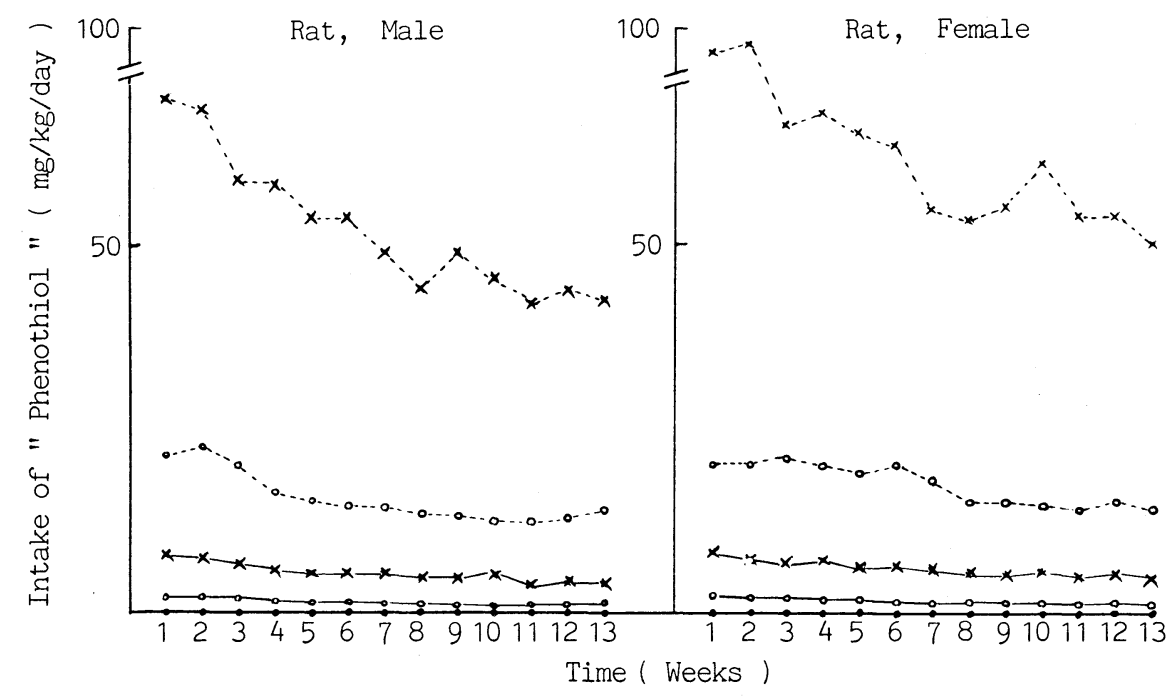

Fig. 8. Intake of "Phenothiol" by Rats 
Table 2. Average Intake of "Phenothiol"

\begin{tabular}{|c|c|c|c|c|}
\hline & \multicolumn{2}{|c|}{ Mouse } & \multicolumn{2}{|c|}{ Rat } \\
\hline & Male & Female & Male & Female \\
\hline Control & 0 & 0 & 0 & 0 \\
\hline I & 3.7 & $4.1^{\prime}$ & 1.6 & 1.9 \\
\hline II & 12.3 & 14.0 & 5.5 & 6.3 \\
\hline III & 35.1 & 42.6 & 15.7 & 17.7 \\
\hline IN & 130.9 & 150.3 & 52.5 & 61.7 \\
\hline
\end{tabular}

(5) Organ weight

Weight of lung, heart, kidney, adrenal gland, testis or ovary, spleen, liver, stomach and brain was measured and ratios of each organ weight to body weight were compared (Table 3 and 4). There is no specific

Table 3. Organ Weight and Its Ratio to Body Weight for Mice

Upper Numbers represent organ weight $(\mathrm{g})$

Lower Numbers represent its ratio to body weight $(\%)$

\begin{tabular}{|c|c|c|c|c|c|c|c|c|c|}
\hline \multirow[t]{2}{*}{ a } & \multicolumn{9}{|c|}{ Mouse , Male } \\
\hline & Lung & Heart & Kidney & $\begin{array}{l}\text { Adrenal } \\
\text { Gland }\end{array}$ & Testis & Spleen & Liver & Stomach & Brain \\
\hline \multirow{2}{*}{ Control } & 0.184 & 0.156 & 0.516 & 0.004 & 0.265 & 0.104 & 1.649 & 0.257 & 0.462 \\
\hline & 0.53 & 0.41 & 1.48 & 0.02 & 0.76 & 0.30 & 4.70 & 0.73 & 1.32 \\
\hline \multirow{2}{*}{ I } & 0.186 & 0.159 & 0.515 & 0.003 & 0.213 & 0.091 & 2.186 & 0.291 & 0.460 \\
\hline & 0.47 & 0.40 & 1.30 & 0.01 & 0.54 & 0.23 & 5.51 & 0.73 & 1.16 \\
\hline \multirow{2}{*}{ II } & 0.229 & 0.197 & 0.530 & 0.004 & 0.322 & 0.141 & 1.980 & 0.344 & 0.461 \\
\hline & 0.59 & 0.51 & 1.28 & 0.02 & 0.84 & 0.37 & 5.13 & 0.90 & 1.20 \\
\hline \multirow{2}{*}{ III } & 0.186 & 0.170 & 0.526 & 0.004 & 0.225 & 0.152 & 1.963 & 0.287 & 0.457 \\
\hline & 0.43 & 0.41 & 1.25 & 0.02 & 0.56 & 0.35 & 4.88 & 0.73 & 1.13 \\
\hline \multirow{2}{*}{ IN } & 0.181 & 0.163 & 0.507 & 0.002 & 0.262 & 0.109 & 1.694 & 0.263 & 0.442 \\
\hline & 0.49 & 0.44 & 1.35 & 0.01 & 0.75 & 0.25 & 4.51 & 0.70 & 1.18 \\
\hline \multirow[t]{2}{*}{$\mathrm{b}$} & \multicolumn{9}{|c|}{ Mouse, Female } \\
\hline & Lung & Heart & Kidney & $\begin{array}{l}\text { Adrenal } \\
\text { Gland }\end{array}$ & Ovary & Spleen & Liver & Stomach & Brain \\
\hline \multirow{2}{*}{ Control } & 0.162 & 0.116 & 0.335 & 0.006 & 0.019 & 0.112 & 1.341 & 0.254 & 0.477 \\
\hline & 0.54 & 0.39 & 1.10 & 0.02 & 0.07 & 0.38 & 4.49 & 0.85 & 1.69 \\
\hline \multirow{2}{*}{ I } & 0.176 & 0.136 & 0.366 & 0.006 & 0.025 & 0.112 & 1.230 & 0.272 & 0.484 \\
\hline & 0.57 & 0.44 & 1.18 & 0.02 & 0.08 & 0.36 & 3.96 & 0.89 & 1.56 \\
\hline \multirow{2}{*}{ II } & 0.165 & 0.119 & 0.343 & 0.006 & 0.022 & 0.111 & 1.218 & 0.237 & 0.464 \\
\hline & 0.52 & 0.38 & 1.08 & 0.04 & 0.07 & 0.35 & 3.83 & 0.75 & 1.46 \\
\hline \multirow{2}{*}{ III } & 0.173 & 0.129 & 0.339 & 0.011 & 0.024 & 0.099 & 1.150 & 0.252 & 0.500 \\
\hline & 0.59 & 0.43 & 1.13 & 0.04 & 0.08 & 0.33 & 3.80 & 0.85 & 1.62 \\
\hline \multirow{2}{*}{ IV } & 0.159 & 0.128 & 0.292 & 0.010 & 0.021 & 0.127 & 1.172 & 0.270 & 0.470 \\
\hline & 0.56 & 0.44 & 0.99 & 0.02 & 0.07 & 0.44 & 3.95 & 0.88 & 1.59 \\
\hline
\end{tabular}


Table 4. Organ Weight and Its Ratio to Body Weight for Rats

Upper Numbers represent organ weight $(g)$

Lower Numbers represent its ratio to body weight (\%)

\begin{tabular}{|c|c|c|c|c|c|c|c|c|c|}
\hline \multirow[t]{2}{*}{$\mathrm{a}$} & \multicolumn{9}{|c|}{ Rat, Male } \\
\hline & Lung & Heart & Kidney & $\begin{array}{c}\text { Adrenal } \\
\text { Gland }\end{array}$ & Testis & Spleen & Liver & Stomach & Brain \\
\hline \multirow{2}{*}{ Control } & 1.238 & 0.889 & 2.090 & 0.035 & 3.023 & 0.561 & 9.673 & 1.282 & 1.929 \\
\hline & 0.40 & 0.27 & 0.63 & 0.01 & 0.90 & 0.17 & 2.89 & 0.39 & 0.58 \\
\hline \multirow{2}{*}{ I } & 1.495 & 0.898 & 2.048 & 0.031 & 2.849 & 0.528 & 9.982 & 1.270 & 1.893 \\
\hline & 0.46 & 0.28 & 0.63 & 0.01 & 0.93 & 0.17 & 3.07 & 0.39 & 0.57 \\
\hline \multirow{2}{*}{ II } & 1.337 & 0.915 & 1.983 & 0.037 & 3.029 & 0.556 & 9.581 & 1.158 & 1.824 \\
\hline & 0.43 & 0.29 & 0.63 & 0.01 & 0.96 & 0.18 & 3.09 & 0.37 & 0.59 \\
\hline \multirow{2}{*}{ III } & 1.396 & 0.863 & 1.971 & 0.038 & 2.905 & 0.533 & 8.597 & 1.095 & 1.866 \\
\hline & 0.45 & 0.28 & 0.63 & 0.01 & 0.93 & 0.17 & 2.73 & 0.35 & 0.60 \\
\hline \multirow{2}{*}{ IV } & 1.312 & 0.856 & 1.878 & 0.035 & 2.913 & 0.561 & 9.245 & 1.178 & 1.913 \\
\hline & 0.42 & 0.28 & 0.61 & 0.02 & 0.94 & 0.18 & 2.97 & 0.38 & 0.63 \\
\hline \multirow[t]{2}{*}{$\mathrm{b}$} & \multicolumn{9}{|c|}{ Rat, Female } \\
\hline & Lung & Heart & Kidney & $\begin{array}{c}\text { Adrenal } \\
\text { Gland }\end{array}$ & Ovary & Spleen & Liver & Stomach & Brain \\
\hline \multirow{2}{*}{ Control } & 0.987 & 0.624 & 1.238 & 0.044 & 0.074 & 0.420 & 5.905 & 0.866 & 1.788 \\
\hline & 0.50 & 0.32 & 0.64 & 0.03 & 0.04 & 0.22 & 3.11 & 0.45 & 0.92 \\
\hline \multirow{2}{*}{$\mathrm{I}$} & 1.032 & 0.597 & 1.288 & 0.047 & 0.077 & 0.372 & 6.553 & 0.923 & 1.854 \\
\hline & 0.53 & 0.31 & 0.68 & 0.03 & 0.04 & 0.19 & 3.31 & 0.47 & 0.89 \\
\hline \multirow{2}{*}{ II } & 1.075 & 0.692 & 1.373 & 0.048 & 0.087 & 0.402 & 6.130 & 0.944 & 1.720 \\
\hline & 0.59 & 0.37 & 0.73 & 0.03 & 0.05 & 0.22 & 3.29 & 0.50 & 0.91 \\
\hline \multirow{2}{*}{ III } & 0.993 & 0.629 & 1.363 & 0.044 & 0.091 & 0.437 & 5.917 & 0.972 & 1.803 \\
\hline & 0.51 & 0.32 & 0.71 & 0.03 & 0.05 & 0.23 & 3.04 & 0.50 & 0.94 \\
\hline \multirow{2}{*}{ IV } & 0.892 & 0.641 & 1.251 & 0.045 & 0.073 & 0.374 & 5.777 & 0.900 & 1.806 \\
\hline & 0.46 & 0.37 & 0.73 & 0.03 & 0.04 & 0.23 & 3.34 & 0.47 & 0.96 \\
\hline
\end{tabular}

organ weight gain or loss in both sexes of mice and rats.

(6) Hematological tests and biochemical tests

Red blood cells and white blood cells were counted. Hemoglobin and hematocrit were measured. In adition, activity of GOT and GPT was tested (Table 5). There are some small variations, but all data are within a normal range.

(7) Pathological studies

At autopsy, no significant macroscopic pathological changes were detected in organs of mice and rats. Thin-sectioning and staining of organs from mice revealed no effect on the lung, but stromatitis in the 
\begin{tabular}{ll} 
& RBC : red blood cell $\left(\times 10^{6} / \mu 1\right)$ \\
Table 5. Blood Test and Biochemical Examination & HBC : white blood cell $\left(\times 10^{3} / \mu 1\right)$ \\
& Hb $:$ hemoglobin $(\mathrm{g} / \mathrm{dl})$ \\
& $\mathrm{Ht}:$ hematocrit $(\%)$ \\
& $\mathrm{GOT}:$ glutamate oxaloacetate transaminase \\
& GPT $:$ glutamate pyruvate transaminase \\
\hline
\end{tabular}

\begin{tabular}{|c|c|c|c|c|c|c|c|c|c|c|c|c|}
\hline \multirow{3}{*}{$\mathrm{a}$} & \multicolumn{12}{|c|}{ Mouse } \\
\hline & \multicolumn{6}{|c|}{ Male } & \multicolumn{6}{|c|}{ Female } \\
\hline & $\mathrm{RBC}$ & WBC & $\mathrm{Hb}$ & $\mathrm{Ht}$ & GOT & GPT & $\mathrm{RBC}$ & WBC & $\mathrm{Hb}$ & $\mathrm{Ht}$ & GOT & GPT \\
\hline Control & 0.94 & 8.8 & 14.4 & 47.8 & 88.6 & 31.0 & 0.96 & 89.3 & 14.6 & 46.8 & 131.0 & 29.7 \\
\hline I & 1.03 & 8.2 & 13.3 & 43.1 & 187.0 & 28.8 & 0.93 & 83.0 & 13.9 & 44.5 & 325.0 & 30.0 \\
\hline II & 0.92 & 8.2 & 12.8 & 42.2 & 102.2 & 28.0 & 0.96 & 86.6 & 14.6 & 46.4 & 182.5 & 38.0 \\
\hline III & 0.96 & 8.6 & 13.3 & 43.7 & 133.0 & 23.8 & 0.96 & 87.2 & 14.9 & 47.0 & 166.0 & 26.0 \\
\hline IV & 1.03 & 8.9 & 15.6 & 50.0 & 118.7 & 30.1 & 0.98 & 85.3 & 14.3 & 47.2 & 115.2 & 26.2 \\
\hline
\end{tabular}

\begin{tabular}{|c|c|c|c|c|c|c|c|c|c|c|c|c|}
\hline \multirow{3}{*}{ b } & \multicolumn{12}{|c|}{ Rat } \\
\hline & \multicolumn{6}{|c|}{ Male } & \multicolumn{6}{|c|}{ Female } \\
\hline & $\mathrm{RBC}$ & WBC & $\mathrm{Hb}$ & $\mathrm{Ht}$ & GOT & GPT & $\mathrm{RBC}$ & WBC & $\mathrm{Hb}$ & $\mathrm{Ht}$ & GOT & GPT \\
\hline Control & 0.88 & 10.5 & 15.3 & 48.3 & 68.0 & 23.9 & 0.85 & 10.4 & 14.7 & 46.2 & 75.3 & 23.3 \\
\hline I & 0.74 & 10.8 & 15.2 & 48.5 & 68.4 & 23.5 & 0.84 & 9.7 & 14.5 & 45.3 & 78.5 & 34.4 \\
\hline II & 0.84 & 10.4 & 15.0 & 47.7 & 57.6 & 15.5 & 0.82 & 10.1 & 14.5 & 45.6 & 79.1 & 24.8 \\
\hline III & 0.93 & 9.9 & 15.2 & 48.7 & 61.9 & 19.9 & 0.83 & 10.0 & 15.0 & 46.0 & 80.9 & 33.5 \\
\hline IV & 0.88 & 10.0 & 14.7 & 47.2 & 68.6 & 13.3 & 0.80 & 9.8 & 14.1 & 45.1 & 78.9 & 21.6 \\
\hline
\end{tabular}

kidney, increase in poietogenesis in the spleen (Photo 1) and obstruction due to the degeneration of seminiferous tubules in the testis (Photo 2) were detected. These observations were at random in "Phenothiol"-fed and non-fed groups. There was slight change in brain and nervous tissues. Some effects were seen in the highest dose group of female mice.

As for effects on rats, alveolitis (Photo 3), fibrosis (Photo 4) and hyperplasia of lymph follicle in the lung were seen. Lung granuloma and bronchitis were also detected, but these seemed not due to the primary reactions and rather due to the secondary reations following increased infections. There was no significant damage to liver cells except that inflammatory infiltration in the hepatic lobule was seen. However, this observation was made randomly not only in "Phenothiol"-fed groups but also in the control. Hyaline casts and hyaline droplets in proximal renal tubules (Photo 5) were seen in the control as well. Atrophy of splenic lymph follicles (Photo 6) was seen in some rats fed the highest dose of the herbicide. Spermatogenesis in the testis was likely to decline (Photo 7).

Slight erosion (Photo 8) and inflammation were seen in the gastrointestinal tract. No instinct toxicity with increasing doses of "Phenothiol" was apparent.

However, the examination of brain and nervous tissues has shown that atrophy of anterior horn cells (Photo 9) and nerve cells in the brain stem (Photo 10,11,12) and occasionally, loss of nissle body were seen more frequently in individuals with increasing doses of the herbicide. The observations were clearly detected in the highest dose group.

Generally, the effects described above were mild and it is probable that there is no specific toxicity. 


\section{Discussion}

Chlorophenoxy compounds as their salts and esters are probably the most familiar chemicals used for herbicides today. "Phenothiol" is an ester of chlorophenoxyacetate. Acute toxicity test has shown that oral $\mathrm{LD}_{50}$ of "Phenothiol" for mice was 1,670 and $1,610 \mathrm{mg} / \mathrm{kg}$ for male and female, respectively and that rats appeared to be somewhat sensitive with $\mathrm{LD}_{50}$ of 960 and $930 \mathrm{mg} / \mathrm{kg}$, respectively, for male and female. The similar values were obtained between male and female in both animals, indicating that sex did not make difference in toxicity herein reported.

The $\mathrm{LD}_{50}$ in other chlorophenoxyacetate and various salts and esters ranged from 300 to over 1,000 $\mathrm{mg}$ / $\mathrm{kg}$ in several experimental species. ${ }^{1 / 2)}$ Relatively low acute toxicity of "Phenothiol" can be compared with herbicides other than phenoxy compounds. For instance, the oral $\mathrm{LD}_{50}$ of dinitro-orthocresol in rats is $30 \mathrm{mg} /$ $\mathrm{kg}^{10)}$ and that for parapuat is in the range of 30 to $50 \mathrm{mg} / \mathrm{kg} .{ }^{11}$

During the 13 weeks subchronic toxicity test, all groups of animals including the control and "Phenothiol" groups took foods equally well and grew normally. The herbicide was stable and was not degraded throughout the experiments. The average intake calculated for the herbicide was parallel to the increasing amounts of the compounds added to foods. Daily intake of the herbicide ranged up to about 150 $\left(10 \%\right.$ of $\left.\mathrm{LD}_{50}\right)$ and $62\left(6 \%\right.$ of $\left.\mathrm{LD}_{50}\right) \mathrm{mg} / \mathrm{kg}$ for mice and rats, respectively. Intake of water and foods, growth rate of animals, ratios of organ weight to body weight, blood test and biochemical studies were compared for effects of the herbicide. There were small variations in some individuals, but they are in the normal range.

There were some histopathological changes in organs other than brain and nerves of mice and rats. These changes were observed at random in the control and experimental groups, indicating that they are not due to toxicity of the herbicide. However, in view of the reported implication of cerebral and nervous tissue injury, ${ }^{3 / 12}$ it seemed necessary to investigate the effect on brain and nerves. Some abberations were seen in the highest dose group. Rats seemed more sensitive than mice. Under the experimental conditions used in this study, the toxicity of "Phenothiol" was mild, but 4-chloro-2-methyl-phenoxyacetic acid and its ethylester were teratogenic, when much higher concentrations were administered. ${ }^{6 / 7}$

Large doses relative to $\mathrm{LD}_{50}$ were ingested over the experimental period and toxicity was moderate. It is probable that "Phenothiol" is rapidly excreted and does not accumulate in the body, as reported for 4-chloro-2-methylphenoxyacetic acid. ${ }^{13}$

\section{Conclusions}

(1) Acute toxicity test

Peroral $\mathrm{LD}_{50}$ of the mouse was 1,670 and $1,610 \mathrm{mg} / \mathrm{kg}$ for male and female, respectively. That of the rat was 960 and $930 \mathrm{mg} / \mathrm{kg}$, respectively, for male and female. "Phenothiol" has low acute toxicity, when it is given orally.

\section{(2) Subchronic toxicity test}

No difference in intake of diet and water, growth rate, clinical observations, blood tests and biochemical examinations was revealed between the control and "Phenothiol" groups, indicating that the herbicide presents little subchronic toxicity. However, pathological studies suggested that among the highest dose groups fed foods which contained $1,000 \mathrm{ppm}$ of the herbicide, there were some effects on brain and nervous tissues in female mice which ingested $150.3 \mathrm{mg} / \mathrm{kg} / \mathrm{day}$ and in both sexes of rats which ingested 52.5 or $61.8 \mathrm{mg} / \mathrm{kg} /$ day. Based on these observations, minimum toxicity value and maximum safety value are tentatively set as shown in Table 6. Generally, pathological changes are mild. 
Table 6. Minimum Toxicity Value and Maximum Safety Value for Mice and Rats

\begin{tabular}{c|c|c|c}
\hline & & Minimum Toxicity Value & Maximum Safety Value \\
\hline \multirow{4}{*}{ Mouse } & Male & $\begin{array}{c}>130.9 \\
(>1000 \mathrm{ppm})\end{array}$ & $\begin{array}{c}130.9 \\
(1000 \mathrm{ppm})\end{array}$ \\
& Female & 150.3 & 42.6 \\
& $(1000 \mathrm{ppm})$ & $(300 \mathrm{ppm})$ \\
\hline \multirow{2}{*}{ Rat } & Male & 52.5 & 15.7 \\
& \multirow{2}{*}{ Female } & $(1000 \mathrm{ppm})$ & $(300 \mathrm{ppm})$ \\
& & $(1000 \mathrm{ppm})$ & $(300 \mathrm{ppm})$
\end{tabular}

VI. References

1) Rowe, V. K. and Hymas, T. A. : Summary of Toxicological Information on 2, 4-D and 2, 4, 5-T Type Herbicide and an Evaluation of Hazards to Livestock Associated with Their Use, Am. J. Vet. Res., 15, 622-629 (1954).

2 ) Dalgaard-Mikkelsen, S. and Poulsen, E. : Toxicology of Herbicides, Pharmacol. Rev., 14, 225-250 (1962).

3 ) Desi, I., Sos, J., Sulw, F. and Markus, V. : Nervous System Effects of A Chemical Herbicide, Arch. Environ. Health, 4, 95-102 (1962).

4 ) Seabury, J. H.: Toxicity of 2, 4-Dichlorophenoxyacetic Acid for Man and Dog, Arch. Environ. Health, 7, 202-209 (1963).

5 ) Kay, J. H., Palazzolo, R. J. and Calandra, J. C. : Subacute Dermal Toxicity of 2, 4-D, Arch. Environ. Health, 11, 648-652 (1965).

6 ) Courtney, K. D. and Moore, J. A. : Teratology Studies with 2, 4, 5-Trichlorophenoxyacetic Acid and 2, 3, 7, 8-Tetrachlorodibenzo-p-dioxin, Toxicol. Appl. Pharmacol., 20, 396-403 (1971).

7 ) Yasuda, M. and Maeda, H.: Teratogenic Effects of 4-Chloro-2-methylphenoxyacetic Acid Ethyl Ester (MCPEE) in Rats, Toxicol. Appl. Pharmacol., 23, 326-333 (1972).

8 ) Shirakawa, M.: Experimental Studies on Subchronic Toxicity of A New Herbicide, "Phenothiol", Jap. J. Hyg., 29, 218 (1974).

9 ) Litchfield, J. T. and Wilcoxon, F. : A Simplified Method of Evaluating Dose-Effect Experiments, J. Pharmacol. Exper. Therap., 96, 99-113 (1949).

10) Hayes, W. J., Jr. : Insecticides, Rodenticides and Other Economic Poisons, In DiPalma, T. R. (ed.) : Drill's Pharmacology in Medicine, 4th ed. McGraw-Hill Book Co., New York, 1971, pp 1256-1276.

11) Conning, D. M., Fletcher, K. and Swan, A. A. : Paraquat and Related Bipyridyls, Br. Med. Bull., 25, 245-249 (1969).

12) Goldstein, N. P., Jones, P. H. and Brown, J. R. : Peripheral Neuropathy after Exposure to An Ester of Dichlorophenoxyacetic Acid, J. A. M. A., 171, 1306-1309 (1959).

13) Lindquist, N. G. : An Autoradiographic Study on the Distribution of the Herbicide 4Chloro-2-methylphenoxyacetic Acid in Pregnant Mice, Toxicol. Appl. Pharmacol., 30, 227-236 (1974). 

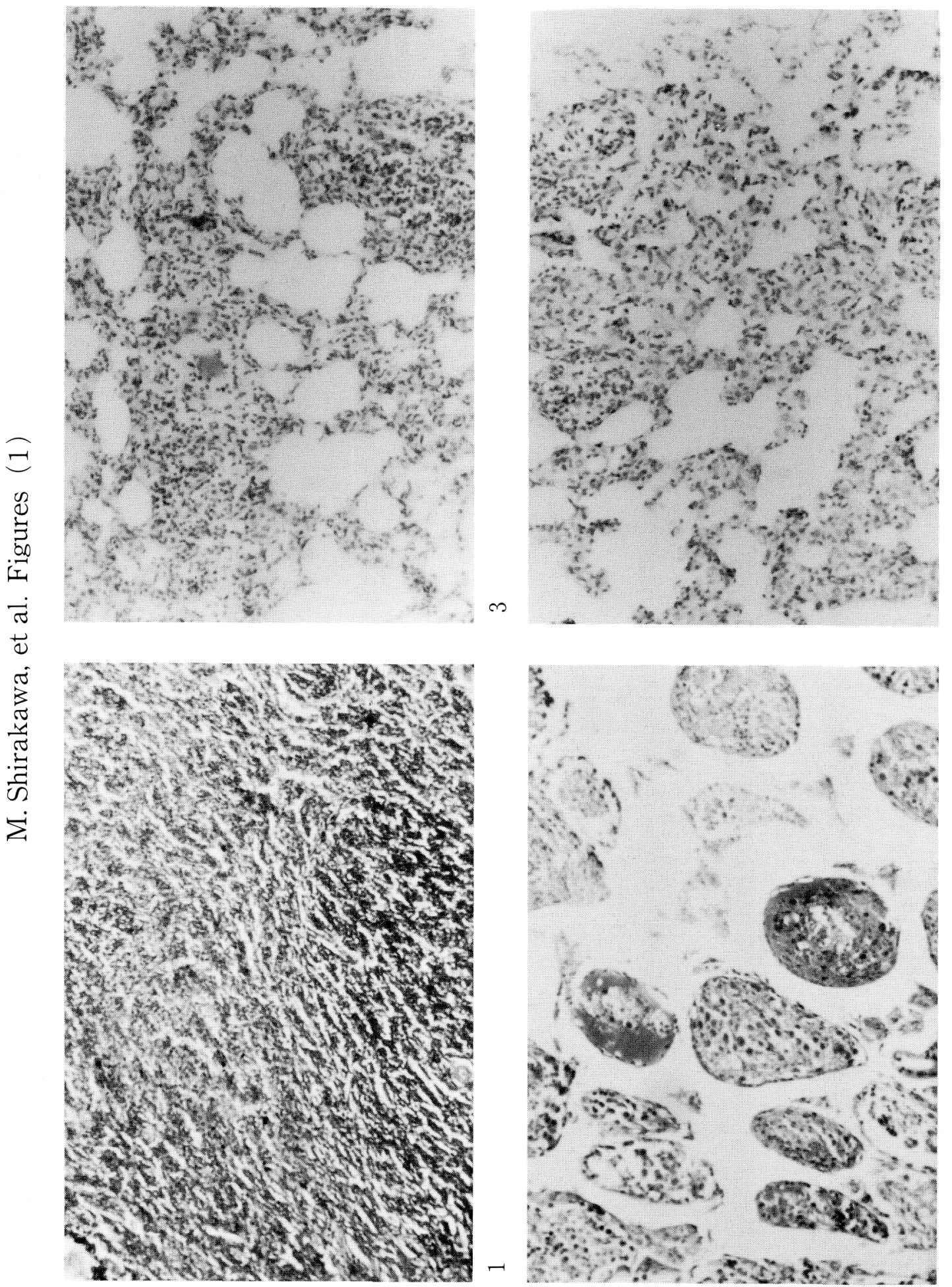

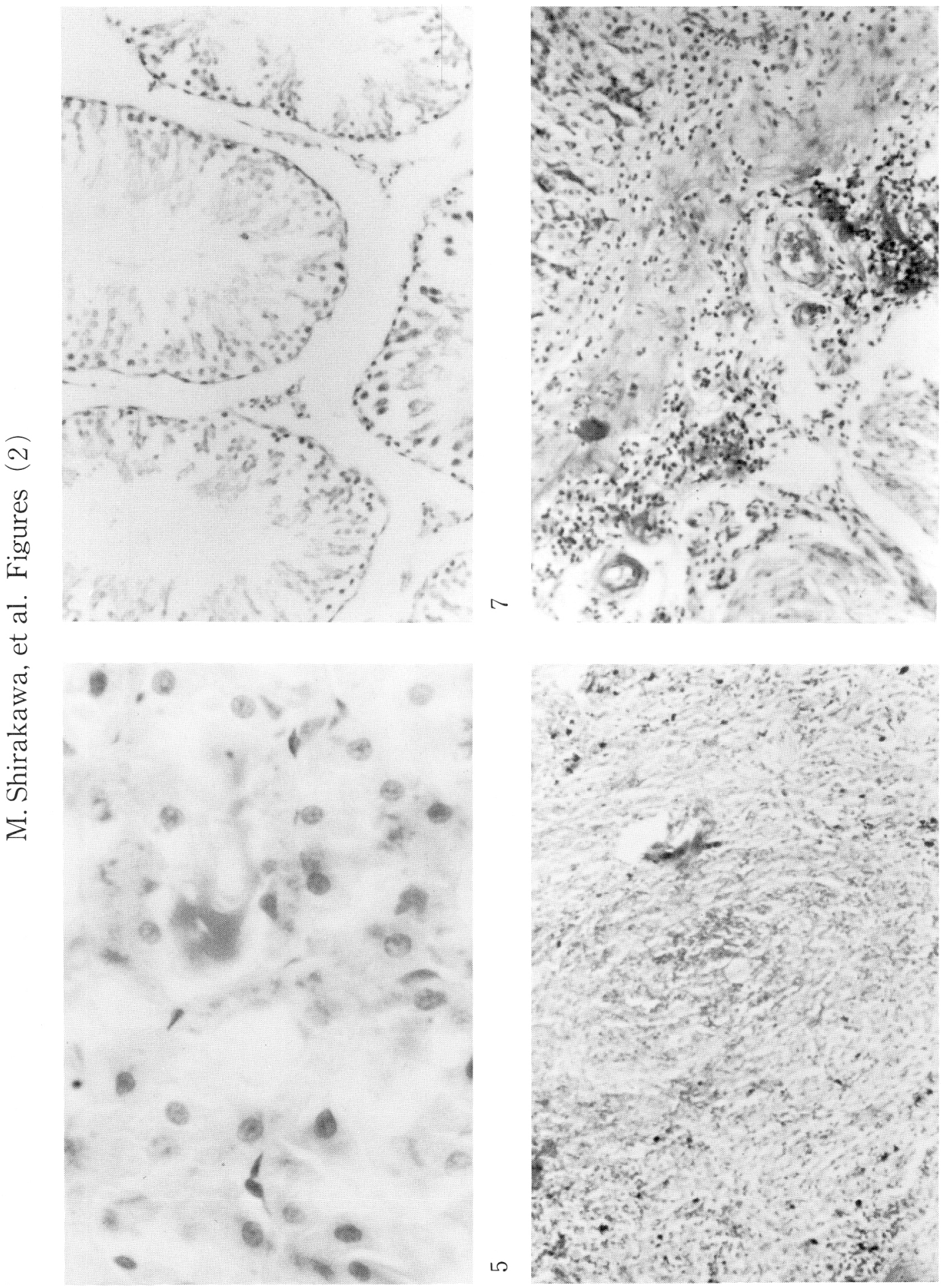
673(23)
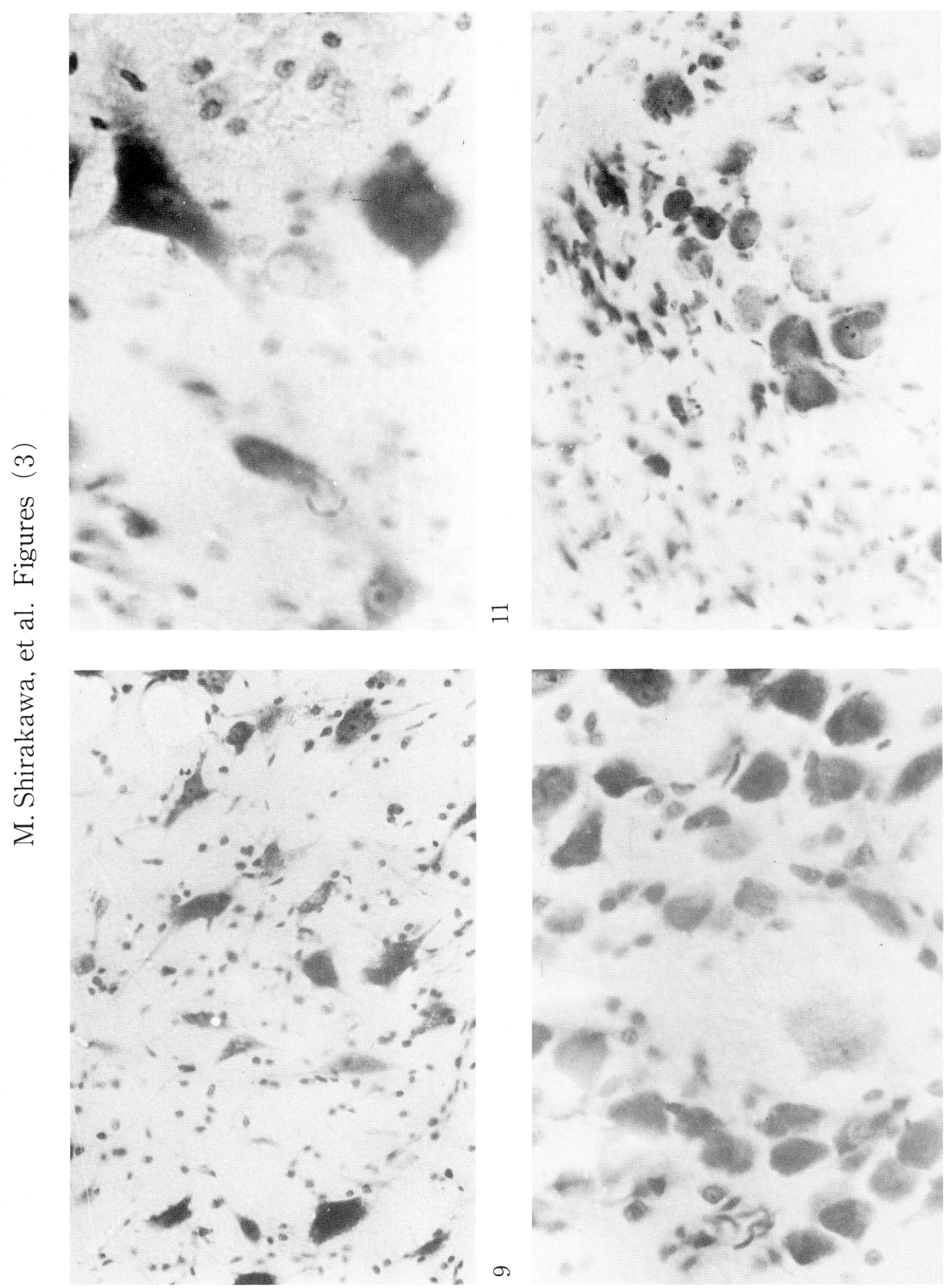

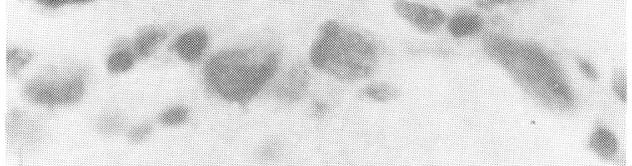
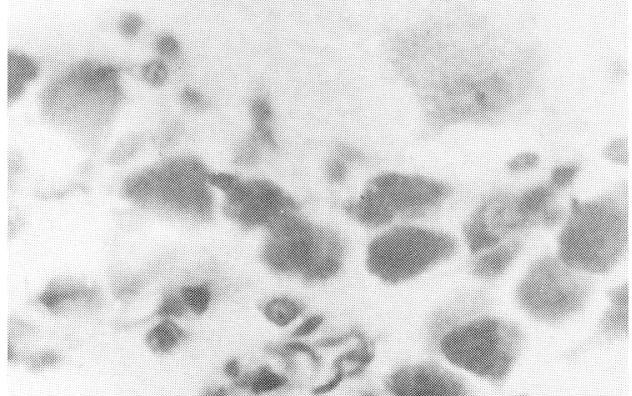
Photo 1. Increase in Hematopoiesis in the Spleen (Mouse, Group II)

Photo 2. Decrease in Spermatogenesis in the Testis and Obstruction of Seminiferous Tubules (Mouse, Group II)

Photo 3. Alveolitis (Rat, Control)

Photo 4. Fibrosis in the Lung (Rat, Group III)

Photo 5. Hyaline Droplet Degeneration and Hyaline Cast (Rat, Group II)

Photo 6. Atrophy of Lymph Follicle in the Spleen (Rat, Group III)

Photo 7. Decrease in Spermatogenesis in the Testis (Rat, Group IV)

Photo 8. Erosion of Mucous Membrane in the Stomach (Rat, Group II)

Photo 9. Mild Atrophy of Anterior Horn Cells in Medulla Oblongata (Rat, Group III)

Photo 10. Degeneration of Olive Nucleus in Medulla Oblongata (Rat, Group IV)

Photo 11. Vacuolization of Terminal Neurons in Medulla Oblongata (Rat, Group IV)

Photo 12. Degeneration of Trigeminal Nerve in Pons (Rat, Group IV)

〈要約〉

PHENOTHIOL のマウスおよびラットにおける急性ならびに 亜慢性毒性試験成績

白川 充, 山口忠敏, 深町征二郎, 菅田節朗 ${ }^{*}$

1．急性毒性試験

マウスの経口 $\mathrm{LD}_{50}$ は雄 $1,670 \mathrm{mg} / \mathrm{kg}$, 雌 $1,610 \mathrm{mg} /$ $\mathrm{kg}$ であった。ラットの経口 $\mathrm{LD}_{50}$ は雄 $960 \mathrm{mg} / \mathrm{kg}$, 雌 $930 \mathrm{mg} / \mathrm{kg}$ であった。

\section{2 . 亜慢性毒性試験}

13 週間にわたる亜慢性毒性試験の結果を総括し, Phenothiol の毒性を考察するに, Phenothiol 配合飼 料を各試験動物の食欲に応じて摂取させたこの実験 で，1匹 1 日当りの飼料摂取量は各投与群とも対照群 に比していちじるしい差異はほとんど認められず，ま た平均飲水量についても同様であった。

体重 $1 \mathrm{~kg}$ 当りの Phenothiol 摂取量も, マウスおよ びラットの雌雄において，ほぼ同様の摂取状況を示し た。

マウスならびにラットに対する各飼料投与群におけ るその体重曲線, 飼料摂取量, 臨床所見, 血液所見, および生化学的所見などを対照群に比べてみると, こ れらの間にはほとんど著明なる差異を認める事はでき ず，ただ病理組織学的所見として，一般諸臓器には特
異所見を見出しえないが，脳神経系の病変がマウス雌， ラットの雌雄などの $1,000 \mathrm{ppm}$ 投与群にやや多く認 められることにより, 最少中毒量打よび最大安全量を 次のように決定した。

\begin{tabular}{|c|c|c|}
\hline 動 物 & $\begin{array}{l}\text { 最少中毒量 } \\
(\mathrm{mg} / \mathrm{kg} / \text { day })\end{array}$ & $\begin{array}{l}\text { 最大安全量 } \\
(\mathrm{mg} / \mathrm{kg} / \mathrm{day})\end{array}$ \\
\hline マウス（雄） & $\begin{array}{c}130.9 \text { 以上 } \\
(1,000 \mathrm{ppm} \text { 以上 })\end{array}$ & $\begin{array}{c}130.9 \\
(1,000 \mathrm{ppm})\end{array}$ \\
\hline マウス（雌） & $\begin{array}{c}150.3 \\
(1,000 \mathrm{ppm})\end{array}$ & $\begin{array}{c}42.6 \\
(300 \mathrm{ppm})\end{array}$ \\
\hline ラツト (雄) & $\begin{array}{c}52.5 \\
(1,000 \mathrm{ppm})\end{array}$ & $\begin{array}{c}15.7 \\
(300 \mathrm{ppm})\end{array}$ \\
\hline ラット（雌） & $\begin{array}{c}61.8 \\
(1,000 \mathrm{ppm})\end{array}$ & $\begin{array}{c}22.5 \\
(300 \mathrm{ppm})\end{array}$ \\
\hline
\end{tabular}

* 宮崎医科大学衛生学教室（主任：白川充教授） 受付：昭和 54 年 7 月 23 日 